\title{
EKSTRAK KEDELAI DETAM 1, DAUN JATI BELANDA SERTA KOMBINASINYA TERHADAP BERAT BADAN DAN HISTOPATOLOGIS HEPAR TIKUS WISTAR
}

\author{
Meilinah Hidayat ${ }^{1}$, Sylvia Soeng ${ }^{2}$, Roro Wahyudianingsih ${ }_{5}^{3}$, Jeanny Ervie Ladi ${ }^{4}$, \\ Yonathan Ari Krisetya ${ }^{5}$, Vera Elviora ${ }^{5}$ \\ ${ }^{1}$ Bagian Nutrisi, Fakultas Kedokteran, Universitas Kristen Maranatha, \\ ${ }^{2}$ Bagian Biologi, Fakultas Kedokteran, Universitas Kristen Maranatha, \\ ${ }^{3}$ Bagian Patologi Anatomi, Fakultas Kedokteran, Universitas Kristen Maranatha, \\ ${ }^{4}$ Bagian Histologi, Fakultas Kedokteran, Universitas Kristen Maranatha, \\ ${ }^{5}$ Fakultas Kedokteran, Universitas Kristen Maranatha,
}

\begin{abstract}
ABSTRAK
Latar Belakang

Biji kedelai Detam 1 dan daun jati Belanda berefek menghambat kenaikan berat badan, akan tetapi dikhawatirkan mempengaruhi organ hepar.

\section{Tujuan penelitian}

Tujuan penelitian untuk mengetahui efek ekstrak etanol biji kedelai Detam 1 (EEKD), ekstrak etanol daun jati Belanda (EEJB) dan kombinasinya terhadap penghambatan kenaikan berat badan dan gambaran histopatologis hepar pada tikus Wistar yang diberi pakan tinggi lemak (PTL).

\section{Metode penelitian}

Penelitian merupakan eksperimental laboratorium dengan rancangan acak lengkap bersifat komparatif. Sebanyak 40 ekor tikus Wistar jantan dibagi secara acak menjadi 8 kelompok perlakuan, masing masing terdiri dari 5 ekor. Selanjutnya diberi perlakuan selama 28 hari, semua kelompok kecuali kelompok kontrol negatif (KN), tetap diberi PTL. Pada hari ke-29, seluruh tikus dikorbankan dan semua hepar tikus, kecuali kelompok Orlistat (K6), dibuat sediaan histopatologis dengan pewarnaan Haematoxylin Eosin (HE).
\end{abstract}

\section{Hasil}

Penghambatan kenaikan berat badan terjadi pada semua kelompok perlakuan, kelompok K3 (EEKD $10 \mathrm{mg}$ : EEJB $20 \mathrm{mg}$ ) menunjukkan penghambatan kenaikan berat badan yang paling baik dan potensinya setara dengan kontrol positip (KP) atau Orlistat. Pada semua kelompok perlakuan (K1, K2, K3, K4 dan K5) terjadi perubahan struktur arsitektur dan inflamasi di daerah portal namun tidak menyebabkan bengkak keruh dan degenerasi lemak.

Kesimpulan: Pemberian kombinasi EEKD $10 \mathrm{mg}$ : EEJB $20 \mathrm{mg}$ menunjukkan penghambatan kenaikan berat badan yang paling baik. EEJB sediaan tunggal menyebabkan perubahan gambaran histopatologis hepar paling buruk pada tikus Wistar jantan yang diinduksi pakan tinggi lemak.

Kata kunci : kedelai Detam 1, jati Belanda, berat badan, histopatologis hepar, Tikus Wistar 


\section{ABSTRACT}

\section{Background}

Detam 1 soybeans and Jati Belanda leaves have inhibitory weight gain effects. In the purpose to inhibit weight gain, it can harm the liver organ.

\section{Objective}

This study was carried-out to find the effects of ethanol extract of Detam 1 soybeans and ethanol extract of Jati Belanda leave and their combinations in decreasing body weight and liver's histopathological changes on male Wistar rats induced high-fat feed .

\section{Method}

The method of the research was true laboratory experiments with a comparative Completely Randomized Design (CRD) which used 40 rats. Experimental animals were divided into 8 groups $(n=5)$. The treatments were administered for 28 days. On the $29^{\text {th }}$ day, all rats were sacrificed and their livers were made into histopathology slide using Haematoxylin Eosin (HE) coloring technique.

\section{Results}

All treatments showed inhibitory weight gain effects and the best is administrations of combination of EEDS $10 \mathrm{mg}$ and EEJB $20 \mathrm{mg}$. All treatments caused liver architecture structure changes and inflammation in portal area but did not caused cloudy swelling and fatty degeneration in male Wistar rats liver, and the EEJB caused the worst.

\section{Conclusion}

Administrations of combination of EEDS $10 \mathrm{mg}$ and EEJB $20 \mathrm{mg}$ give the best result to prevent weight gain and EEJB caused the worst changes in liver histopathological features.

Keywords : Detam 1 soybean, Jati Belanda, weight gain, liver's histopathological, Wistar Rats

\section{PENDAHULUAN}

Biji kedelai Detam 1 dan daun jati Belanda merupakan tanaman yang mempunyai banyak senyawa aktif berkhasiat. Salah satu efeknya adalah mampu menghambat kenaikan berat badan, akan tetapi pemberian untuk tujuan penurunan berat badan dikhawatirkan mempengaruhi organ hepar. Hasil penelitian terdahulu oleh Hidayat M dkk, ekstrak etanol biji kedelai Detam 1 (EEKD) terbukti mengandung fenolik, flavonoid $\mathrm{H}_{2} \mathrm{SO}_{4}$ triterpenoid, steroid, saponin, kuinon dan tannin, namun tidak mengandung alkaloid. ${ }^{1}$ Ekstrak etanol daun jati Belanda (EEJB) terbukti mengandung fenolik, flavonoid $\mathrm{H}_{2} \mathrm{SO}_{4}$ triterpenoid, kuinon dan tannin, tetapi tidak mengandung steroid, saponin dan alkaloid. ${ }^{1}$

Penelitian-penelitian sebelumnya juga membuktikan bahwa EEKD dan EEJB dapat menginhibisi enzim lipase 
pankreas, ${ }^{2,3}$ menurunkan kadar kolesterol total, ${ }^{4,5}$ dan menurunkan berat badan. ${ }^{1,6,7}$

Tujuan penelitian ini adalah untuk mengetahui efek pemberian EEKD, EEJB dan kombinasinya terhadap penghambatan kenaikan berat badan dan perubahan gambaran histopatologis hepar tikus Wistar jantan yang diinduksi pakan tinggi lemak.

\section{BAHAN DAN METODE}

Penelitian ini dilakukan di laboratorium Farmakologi dan laboratorium Patologi Anatomi Fakultas Kedokteran Universitas Kristen Maranatha Bandung, laboratorium Farmakologi Fakultas Kedokteran Universitas Padjadjaran Bandung, pada April 2014 - Januari 2015. Telah mendapat persetujuan komite Etik Penelitian FK Maranatha dan RSI Immanuel Bandung.

Bahan penelitian yang digunakan adalah kedelai unggulan varietas Detam 1 yang ditanam di perkebunan Balitkabi Malang $^{8}$ dan daun jati Belanda yang ditanam di perkebunan Bumi Herbal Dago. Kedua bahan ini kemudian dibuat ekstrak etanol menggunakan proses maserasi sederhana. ${ }^{9}$

Sebanyak 40 tikus putih galur Wistar jantan berumur \pm 11 minggu dengan berat antara 250 - $300 \mathrm{~g}$, setelah diadaptasi selama 7 hari, dikelompokkan secara acak menjadi 8 kelompok, masing-masing 5 ekor tikus. Selanjutnya semua kelompok, kecuali kelompok KN, diinduksi pakan tinggi lemak selama 14 hari. Dilanjutkan dengan dengan pemberian perlakuan selama 28 hari. KN : Kontrol negatif, diberi pakan standar; KP : Kontrol positif, diberi pakan tinggi lemak tanpa perlakuan, hanya pemberian aquadest; K1 : diberi pakan tinggi lemak dengan pemberian EEKD $10 \mathrm{mg}$ : EEJB 10 mg; K2 : diberi pakan tinggi lemak dengan pemberian EEKD $20 \mathrm{mg}$ : EEJB $10 \mathrm{mg}$; K3 : diberi pakan tinggi lemak dengan pemberian EEKD $10 \mathrm{mg}$ : EEJB $20 \mathrm{mg}$; K4 : diberi pakan tinggi lemak dengan pemberian EEKD $20 \mathrm{mg} /$ ekor/ hari; K5 : diberi pakan tinggi lemak dengan pemberian EEJB $20 \mathrm{mg} /$ ekor/ hari; K6 : diberi pakan tinggi lemak dengan pemberian Orlistat 2,16 mg/kgBB/ hari. Semua tikus ditimbang berat badannya setiap 2 hari sekali, diberi perlakuan selama 28 hari.

Pada hari ke-29, semua tikus dikorbankan dan hepar kelompok K1, K2, K3, K4 dan K5 dibuat sediaan histopatologis dengan pewarnaan Haematoxylin Eosin $(\mathrm{HE})^{10}$ selanjutnya diamati di bawah mikroskop cahaya dengan perbesaran 100x dan 400x. Parameter yang 
dinilai adalah perubahan struktur arsitektur, bengkak keruh, degenerasi lemak dan inflamasi daerah portal. $^{11}$

\section{Penilaian Stuktur Arsitektur:}

- normal : bila tidak ada terganggu dalam 10 lapang pandang

- terganggu ringan minimal : bila terganggu $<10 \%$ dari 10 lapang pandang

- terganggu ringan : bila terganggu 1025\% dalam 10 lapang pandang

- terganggu sedang : bila terganggu 26$50 \%$ dalam 10 lapang pandang
$<10 \%$ dalam 10 lapang pandang

- ringan : bila terdapat inflamasi $10-25 \%$ dalam 10 lapang pandang

- sedang : bila terdapat inflamasi 26-50\% dalam 10 lapang pandang

- berat : bila terdapat inflamasi $50-75 \%$ dalam 10 lapang pandang

- sangat berat : bila terdapat inflamasi $>75 \%$ dalam 10 lapang pandang

\section{Penilaian Degenerasi Bengkak Keruh:}

Sitoplasma terlihat membengkak dan keruh akibat akumulasi cairan.

Tabel 1. Data Berat Badan dan Persentase Kenaikan Berat Badan Tikus Wistar yang diberi Perlakuan EEKD, EEJB dan Kombinasinya

\begin{tabular}{cccc}
\hline Kelompok & $\begin{array}{c}\text { Berat Badan AWAL } \\
\text { hari ke 15 } \\
\text { (dalam gr) }\end{array}$ & $\begin{array}{c}\text { Berat Badan AKHIR hari } \\
\text { ke } \mathbf{4 2} \\
\text { (dalam gr) }\end{array}$ & $\begin{array}{c}\text { \%enaikan Berat } \\
\text { Badan }\end{array}$ \\
\hline $\mathrm{KN}$ & 213 & 270 & $21 \%$ \\
\hline $\mathrm{KP}$ & 236.5 & 280 & $18.7 \%$ \\
\hline $\mathrm{K} 1$ & 203 & 243 & $15 \%$ \\
\hline $\mathrm{K} 2$ & 227 & 249 & $8.5 \%$ \\
\hline $\mathrm{K} 3$ & 180 & 200 & $5.9 \%$ \\
\hline $\mathrm{K} 4$ & 211 & 261 & $18,42 \%$ \\
\hline $\mathrm{K} 5$ & 213 & 248 & $0,9 \%$ \\
\hline $\mathrm{K} 6$ & 213 & 214 & \\
\hline
\end{tabular}

- terganggu berat : bila terganggu 50-75\% dalam 10 lapang pandang

- terganggu sangat berat : bila terganggu $>75 \%$ dalam 10 lapang pandang

\section{Penilaian Inflamasi di daerah portal :}

- normal : bila tidak terdapat inflamasi dalam 10 lapang pandang

- sedikit sekali : bila terdapat inflamasi

\section{HASIL DAN PEMBAHASAN}

Setelah didapatkan masing-masing rerata dari berat badan tikus per kelompok perlakuan, kemudian dilakukan penghitungan terhadap rerata persentase kenaikan berat badan tikus setelah induksi dan setelah perlakuan. Hasil rerata persentase kenaikan berat badan tikus, yaitu 
rerata berat badan akhir dikurangi rerata berat badan awal, dibagi rerata berat badan akhir (Tabel 1 dan Gambar 1). $\mathrm{mg}$ : EEJB $20 \mathrm{mg})(5,9 \%), \mathrm{K} 2$ (EEKD 20 $\mathrm{mg}$ : EEJB $10 \mathrm{mg})(8,5 \%), \mathrm{K} 5$ (EEJB 20mg) (14,3\%), K1 (EEKD 10 mg: EEJB

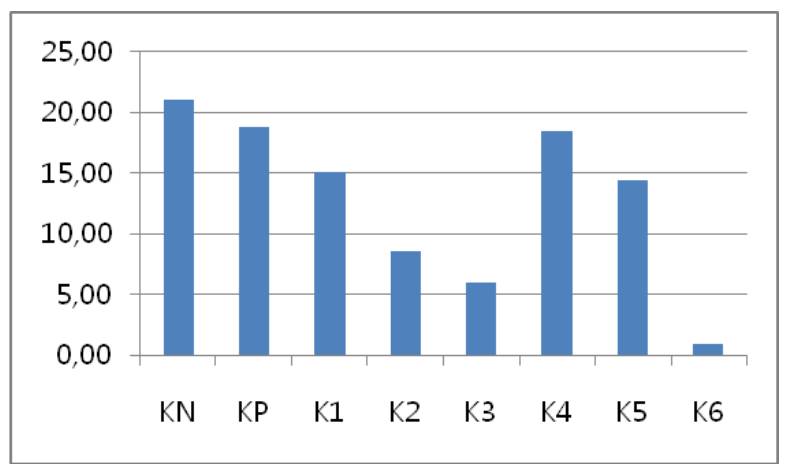

Gambar 1. Persentase Kenaikan Berat Badan Tikus Wistar yang diberi Perlakuan EEKD, EEJB dan Kombinasinya

Tabel 1 dan Gambar 1 menunjukkan $10 \mathrm{mg}$ ) (15\%), dan K4 (EEKD $20 \mathrm{mg}$ ) bahwa persentase kenaikan berat badan $(18,42 \%)$.

Tabel 2. Analisis Persentase Kenaikan Berat Badan Tikus dengan Tukey HSD (1)

\begin{tabular}{|c|c|c|c|c|c|c|c|c|}
\hline & KN & $\mathbf{K P}$ & K1 & K2 & K3 & K4 & K5 & K6 \\
\hline $\mathbf{K N}$ & & NS & NS & $* \mathrm{p}=0.000$ & $\begin{array}{c}* * \\
\mathrm{p}=0.001\end{array}$ & NS & $* \mathrm{p}=0.046$ & $\begin{array}{c}* * \\
\mathrm{p}=0.000\end{array}$ \\
\hline $\mathbf{K P}$ & & & NS & $* * \mathrm{p}=0.003$ & $\begin{array}{l}* * \mathrm{p}= \\
0.000\end{array}$ & NS & NS & $\begin{array}{c}* * \\
\mathrm{p}=0.000\end{array}$ \\
\hline K1 & & & & NS & $\begin{array}{c}* * \\
\mathrm{p}=0.008\end{array}$ & NS & NS & $\begin{array}{c}* * \\
\mathrm{p}=0.000\end{array}$ \\
\hline $\mathbf{K 2}$ & & & & & NS & $\begin{array}{c}* * \\
\mathrm{p}=0.004\end{array}$ & NS & $* \mathrm{p}=0.025$ \\
\hline $\mathbf{K 3}$ & & & & & & $\begin{array}{c}* * \\
\mathrm{p}=0.004\end{array}$ & $* p=0.009$ & NS \\
\hline K4 & & & & & & & $\mathrm{NS}$ & $\begin{array}{c}* * \\
\mathrm{p}=0.000\end{array}$ \\
\hline K5 & & & & & & & & $\begin{array}{c}* * \\
\mathrm{p}=0.006\end{array}$ \\
\hline K6 & & & & & & & & \\
\hline
\end{tabular}

paling besar adalah kontrol negatif (21\%),

Analisis data menggunakan ANAVA diikuti kontrol positif (18,7\%). Dari $\alpha=0,05$ menunjukkan hasil yang sangat kelompok perlakuan, persentase kenaikan bermakna $(0,000)$, hal ini berarti minimal berat badan paling kecil adalah kelompok ada sepasang perlakuan yang berbeda K6 (orlistat) (0,9\%), diikuti K3 (EEKD 10 (p<0,01). Maka dilanjutkan dengan uji 
Tukey HSD, dan hasilnya dapat dilihat pada Tabel 2.

Kelompok perlakuan K2 dan K3 berbeda sangat bermakna dengan KP, berarti pemberian kombinasi EEKD 20 $\mathrm{mg}$ : EEJB $10 \mathrm{mg}$ dan EEKD $10 \mathrm{mg}$ : EEJB $20 \mathrm{mg}$ terbukti menghambat kenaikan berat badan tikus. Kelompok K2 berbeda sangat tunggal kedelai atau daun Jati Belanda dalam menghambat kenaikan berat badan tikus. ${ }^{1,6}$

Kelompok K2 dan K3 berbeda tidak bermakna dengan kelompok K6, ini menunjukkan bahwa pemberian kombinasi EEKD $20 \mathrm{mg}$ : EEJB $10 \mathrm{mg}$ dan EEKD 10 $\mathrm{mg}$ : EEJB $20 \mathrm{mg}$ mempunyai potensi yang

Tabel 3. Gambaran Histopatologis Hepar Tikus yang diberi Perlakuan EEKD, EEJB dan Kombinasinya

\begin{tabular}{cccccc}
\hline & Arsitektur & $\begin{array}{l}\text { Bengkak } \\
\text { Keruh }\end{array}$ & $\begin{array}{c}\text { Degenerasi } \\
\text { Lemak }\end{array}$ & $\begin{array}{c}\text { Inflamasi di Daerah } \\
\text { Portal }\end{array}$ & TOTAL SKOR \\
\hline KN & Normal (0) & Tidak ada (0) & Tidak ada & Tidak ada (0) & 0 \\
\hline KP & $\begin{array}{c}\text { Terganggu ringan } \\
\text { sekali } \sim \text { Normal }(0)\end{array}$ & Ada (1) & Tidak ada & Ringan (2) & 3 \\
\hline K1 & $\begin{array}{c}\text { Terganggu ringan } \\
\text { minimal (1) }\end{array}$ & Tidak ada (0) & Tidak ada & Ringan (2) & 3 \\
\hline K2 & $\begin{array}{c}\text { Terganggu ringan (2) } \\
\text { Tergak ada (0) }\end{array}$ & Tidak ada & Ringan (2) & 4 \\
\hline K3 & Terganggu sedang (3) & Tidak ada (0) & Tidak ada & Ringan (2) & $\mathbf{5}$ \\
\hline K4 & $\begin{array}{c}\text { Terganggu ringan } \\
\text { sekali } \sim \text { Normal (0) }\end{array}$ & Tidak ada (0) & Tidak ada & Sedikit sekali (1) & 1 \\
\hline K5 & Terganggu berat (4) & Tidak ada (0) & Tidak ada & Sedang (3) & 7 \\
\hline
\end{tabular}

bermakna dengan Kelompok K4, namun berbeda tidak bermakna dengan Kelompok K5, berarti pemberian kombinasi EEKD 20 $\mathrm{mg}$ : EEJB $10 \mathrm{mg}$ lebih baik daripada pemberian ekstrak tunggal kedelai. Kelompok K3 berbeda sangat bermakna dengan Kelompok K4 dan berbeda bermakna dengan $\mathrm{K} 5$, berarti pemberian kombinasi EEKD : EEJB $10 \mathrm{mg}$ : $20 \mathrm{mg}$ lebih baik daripada pemberian ekstrak setara dengan Orlistat dalam menghambat kenaikan berat badan tikus, namun secara persentase, pemberian EEKD $10 \mathrm{mg}$ : EEJB $20 \mathrm{mg}$ menghambat kenaikan berat badan yang paling baik. ${ }^{1,6}$

Selanjutnya dilakukan penilaian gambaran histopatologis hepar tikus Wistar jantan yang diinduksi pakan tinggi lemak dengan perlakuan pemberian EEKD, EEJB dan kombinasinya. Parameter yang dinilai 
adalah Arsitektur hati, Degenerasi bengkak keruh, Degenerasi Lemak dan Inflamasi di daerah portal. ${ }^{11,12,13}$ Hasil interpretasi parameter tersebut tercantum pada tabel 3.

\section{PEMBAHASAN}

Dalam keadaan normal, tikus sehat yang dipelihara dengan baik dan berada dalam kondisi seimbang antara konsumsi dan kebutuhan asupan makan, berat badan tikus akan tetap naik mengikuti pola pertumbuhan dan perkembangan sesuai umurnya yaitu sekitar 5 gram per hari ${ }^{7}$ Pada hewan coba yang dipelihara dengan baik, diberi asupan makan yang cukup, tentu terjadi peningkatan berat badan. Pada penelitian ini pemberian perlakuan EEKD dan EEJB dimaksudkan untuk menghambat peningkatan berat badan; sehingga yang dinilai adalah penghambatan kenaikan berat badan hewan coba.

Pada kontrol negatif kenaikan berat badan ternyata lebih besar daripada kontrol positif karena menurut penelitian Bagchi, tikus yang diberi pakan tinggi lemak akan mengalami gangguan pada mukosa ususnya berupa atrofi villi sehingga penyerapan makanan tidak maksimal dan mempengaruhi kenaikan berat badan tikus. $^{14}$
Kelompok EEKD 10 mg : EEJB 20 mg menunjukkan persentase kenaikan berat paling sedikit (5.9\%) dibandingkan dengan kelompok EEKD : EEJB $20 \mathrm{mg}$ : $10 \mathrm{mg}$ (8.5\%), EEJB $20 \mathrm{mg}(14,3 \%)$, dan EEKD $20 \mathrm{mg}(18,42 \%)$, hal ini mendukung penelitian yang sebelumnya dilakukan tentang efek inhibisi enzim lipase pankreas dari ekstrak etanol Kedelai Detam 1 (EEKD) dan ekstrak etanol Jati Belanda (EEJB), dimana kombinasi terbaik adalah EEKD $10 \mathrm{mg}$ : EEJB $20 \mathrm{mg}$.,6

Hasil uji fitokimia ekstrak etanol Biji Kedelai Detam 1 terbukti mengandung fenolik, flavonoid $\mathrm{H}_{2} \mathrm{SO}_{4}$ triterpenoid, steroid, saponin, kuinon dan tannin namun tidak mengandung alkaloid. ${ }^{1}$ Penghambatan kenaikan berat badan tikus karena kedelai Detam 1 terutama mengandung flavonoid, isoflavon. Kadar isoflavon dalam kedelai paling banyak terdapat dalam fraksi etil asetat, dan kadar Daidzein tertinggi dalam fraksi etil asetat biji kedelai Detam 1 yaitu $0,669 \% .{ }^{15}$ Isoflavon, terutama genistein dan daidzein yang menghambat enzim lipase pankreas dan menginduksi apoptosis sel adiposit. Hasil uji fitokimia EEJB varietas Bumi Herbal Dago menunjukkan mengandung fenolik, flavonoid $\mathrm{H}_{2} \mathrm{SO}_{4}$ triterpenoid, kuinon dan tannin, namun tidak mengandung alkaloid steroid dan 
saponin. ${ }^{1}$ Tannin dan flavonoid dalam EEJB merupakan zat aktif utama dalam menghambat kenaikan berat badan.

Penghambatan kenaikan berat badan yang paling baik adalah kombinasi EEKD $10 \mathrm{mg}$ : EEJB $20 \mathrm{mg}$. Kombinasi menyebabkan efek sinergis dari kedua tanaman obat ini dan menyebabkan penghambatan kenaikan berat badan yang lebih baik dibandingkan ekstrak tunggalnya. Kombinasi dengan proporsi EEJB yang lebih besar menunjukkan hasil yang lebih baik akan tetapi terjadi hal yang sebaliknya terhadap gambaran histopatologis hepar. Pemberian EEKD sediaan tunggal lebih sedikit menimbulkan perubahan gambaran histopatologis hepar dibandingkan dengan pemberian EEJB sediaan tunggal. Ekstrak kombinasi dengan proporsi EEKD yang lebih besar menunjukkan gambaran histopatologis hepar yang lebih baik jika dibandingkan dengan pemberian EEJB dalam proporsi yang lebih besar.

Kontrol positif (KP), total jumlah skor 3, hanya pada kelompok ini didapatkan gambaran degenerasi bengkak keruh, berbeda dengan semua kelompok lain, K1, K2, K3, K4, K5. Degenerasi bengkak keruh adalah degenerasi berupa pembengkakan dan kekeruhan sitoplasma akibat akumulasi cairan. Kelainan ini merupakan degenerasi ringan dan bersifat reversibel. ${ }^{16}$ Pemberian pakan tinggi lemak akan menyebabkan meningkatnya free fatty acid yang akan menimbulkan keadaan stress oksidatif atau disfungsi mitokondria. ${ }^{16}$ Adanya morfologi uncoupling antara oksidasi dan fosforilasi akan menyebabkan terjadinya degenerasi bengkak keruh. ${ }^{17}$ Pada kelompok K1, K2, $\mathrm{K} 3$, K4, K5 tidak terdapat bengkak keruh ini dikarenakan kedelai Detam 1 dan jati Belanda mengandung senyawa tannin yang berfungsi untuk menginhibisi enzim lipase pankreas sehingga menghambat terjadinya hidrolisis 1,3-triasilgliserol menjadi 2monoasilgliserol dan free fatty acid. ${ }^{18}$

Pada kelompok KP dan K1, K2, K3, K4, K5 didapatkan inflamasi dengan derajat bervariasi di daerah portal, ini disebabkan karena pemberian pakan tinggi lemak akan menyebabkan terjadinya akumulasi trigliserida dalam hepatosit yang dapat meningkatkan kerentanan akan cedera hati akibat aktivasi sitokin-sitokin inflamasi. ${ }^{18}$

Pada kelompok K2 dan K4 dengan proporsi kedelai Detam 1 lebih besar daripada jati Belanda, didapatkan gambaran yang lebih baik daripada kelompok K3 dan K5 yaitu perubahan arsitektur yang terjadi lebih ringan karena kedelai mengandung isoflavon khususnya genistein. Genistein adalah agen antioksidan yang kuat dan 
secara signifikan menurunkan tingkat TNF alpha plasma dan sangat mencegah munculnya NAFLD dengan meningkatkan kelainan biokimiawi dan histopatologis melalui penurunan stress oksidatif. ${ }^{19}$ Berdasarkan hasil penelitian Leng dkk, isoflavon dapat mengurangi penumpukan lipid pada hepar, serta meningkatkan kapasitas antioksidan. Mekanismenya berhubungan dengan inhibisi SREBP-1c dan aktivasi dari ekspresi PPAR $\alpha$ di hepar. ${ }^{20}$ Hal ini menyebabkan pemberian EEKD menyebabkan perbaikan gambaran histopatologis hepar.

Pada kelompok K3 (total angka skor 5) dan K5, hanya EEJB (total angka skor 7), didapatkan gambaran yang lebih buruk daripada kelompok K2 (total angka skor 3) dan K4, hanya EEKD (total angka skor 1). Perubahan arsitektur yang terjadi lebih berat karena proporsi EEJB lebih besar dari EEKD dan kemungkinan besar daun jati Belanda berefek hepatotoksik. $^{21}$

Metabolit sekunder dalam EEJB yang cukup dominan adalah tannin. Sebagai organ utama yang memetabolisme dan mendetoksifikasi obat dalam tubuh, hepar menjadi target kerusakan potensial dari bermacam senyawa kimia farmasetis dan lingkungan yang tidak terhitung jumlahnya. Cedera dapat merupakan hasil dari toksisitas langsung (direct toxicity) melalui konversi hepar oleh suatu xenobiotik menjadi toksin aktif, atau melalui mekanisme imun, biasanya oleh obat atau metabolit yang berperan sebagai hapten untuk mengubah protein selular menjadi suatu imunogen. ${ }^{21}$ Asam tannat yang merupakan zat aktif tannin, dapat menyebabkan kerusakan atau cedera pada hepar. Gejala bergantung dari tingkat lama paparan dan konsentrasi. ${ }^{22}$ Dalam jumlah yang cukup besar, asam tannat dapat bersifat iritasi, sehingga dapat menimbulkan efek samping dan gejala klinik yang mungkin timbul antara lain: iritasi lambung, mual, muntah dan kerusakan hati. Penggunaan dalam dosis tinggi dan lama dapat memperburuk gangguan hati. $^{23}$ Asam tannat yang terkandung dalam barium enema terbukti potensial bersifat hepatotoksik pada 5 orang kasus dengan gagal hati fulminate fatal dari 213 kasus, selama periode 27 bulan. Zat hepatotoksik dapat bereaksi secara langsung maupun dari hasil metabolitnya yang reaktif dan toksik menyebabkan terganggunya permeabilitas selaput, homeostasis osmosis, keutuhan enzim dan kofaktor yang selanjutnya membebani sel hepar, dan menyebabkan jejas dan perubahan morfologi sel. ${ }^{24}$ 
Pada kelompok K5 yaitu pemberian sediaan tunggal EEJB didapatkan gambaran yang paling buruk bila dibandingkan dengan kelompok K1, K2, K3, K4 karena komposisi EEJB yang mengandung tannin paling banyak, dan berefek hepatotoksik. ${ }^{1,21}$ Pemberian EEJB sediaan tunggal memperburuk gambaran histopatologis hepar dibandingkan dengan ekstrak kombinasi maupun EEKD ekstrak tunggal, walaupun belum terjadi perlemakan hati atau degenerasi lemak.

\section{KESIMPULAN DAN SARAN}

\section{Kesimpulan}

Pemberian kombinasi EEKD 10 $\mathrm{mg}$ : EEJB $20 \mathrm{mg}$ menunjukkan penghambatan kenaikan berat badan yang paling baik. EEJB tunggal menyebabkan perubahan gambaran arsitektur dan inflamasi daerah portal paling buruk pada preparat histopatologis hepar tikus Wistar jantan yang diinduksi pakan tinggi lemak.

\section{SARAN}

Sediaan kombinasi EEKD $10 \mathrm{mg}$ dan EEJB $20 \mathrm{mg}$, memang menunjukkan hasil yang paling baik dalam menurunkan berat badan, akan tetapi dalam penggunaannya harus berhati hati dan tidak digunakan untuk waktu yang lama. Perlu dilakukan uji toksisitas subkronis dari sediaan kombinasi ini, untuk melihat efek terhadap organ hati dalam pemakaian jangka panjang selama 90 hari.

\section{DAFTAR PUSTAKA}

1. Hidayat M, Soeng S, Prahastuti S, Tiono H, Krisetya YA, Sugiono M. Characteristics of Ethanol Extract of Detam 1 Indonesian Soybean, Jati Belanda Leaves and the Effets of their Combinations to Weight Gain and the Jejunum Histopathological Changes in Male Wistar Rats. European Journal Of Medicinal Plants. European Journal of Medicinal Plants. EJMP.2015: 7 (2): 8798.ISSN: 2231-0894

2. Hidayat $M$, Soeng $S$, Prahastuti S. Characteristics of combinations ethanol extract of Detam 1 soybean (Glycine max L. merr) /EEDS and ethanol extract of Jati Belanda Leaves (Guazuma ulmifolia) /EEJB in Potential Inhibition of Pancreas Lipase Enzyme. Proceeding. International Symposium of Natural Products and Medicine, ITB, Bandung. 2012;34.

3. Hidayat M, Soeng S, Prahastuti S. Pengujian Aktivitas Lipase Inhibitor Ekstrak Etanol dan Hasil Fraksionasi dari Kedelai Detam 1 dan Daun Jati Belanda. Jurnal Chimica et Natura Acta. 2014. 2(1): 76-82.

4. Hidayat M, Khiong K, Siswanto MC. Comparison of the Effetcts of Three Sorts of Soybean Extract Detam 1 on the Total Cholesterol Levels in Male Mice Balb-C. The Indonesian Biomedical Journal. InaBJ. Vol 4 No 3 Dec 2012 ISSN 2085-3297. Acredited by LIPI No. 431 / Akred-LIPI / P2MI-LIPI / 04/2012

5. Kwan, M.Y. Efek Ekstrak Etanol Kedelai (Glycine max (L.) Merr.) Varietas Detam 1 Dan Ekstrak Etanol Daun Jati Belanda (Guazuma ulmifolia) Terhdap Kadar Kolesterol Total Tikus Wistar Jantan Yang Diinduksi Pakan Tinggi Lemak. Universitas Kristen Maranatha Bandung : Karya Tulis Ilmiah. 2013.

6. Krisetya, Y.A. Perbandingan Efek Ekstrak Etanol Biji Kedelai (Glycine max L.merr) 
Varietas Detam 1, Ekstrak Etanol Daun Jati Belanda (Guazuma ulmifolia), Dan Kombinasinya Terhadap Penghambatan Kenaikan Berat Badan Tikus Wistar Jantan Dislipidemia. Universitas Kristen Maranatha Bandung : Karya Tulis Ilmiah. 2013.

7. Hidayat M, Kurnia D, Sujatno M, Sutadipura N, Setiawan. Meilinah Hidayat, Muchtan Sujatno, Sutadipura Nugraha, Setiawan (2009). Several Effect of Soybean (Glycine Max L. Merr) Extracts To Food Intake, Body Weight And Plasma Cholecystokinin In Rats. published in Science Magazine Faal Indonesia. Vol 8 No 3.p 151-8. ISSN 0215-1995. Director General of Higher Education Accreditation No. 56 / Higher Education / Kep / 2005

8. Balai Penelitian Tanaman Kacangkacangan dan Umbi-umbian. 2012 Available:http://balitkabi.litbang.deptan.go.i $\mathrm{d} /$ varietas-unggul/vu-kedelai/77varietasunggul-kedelai-detam-1.html

9. Harborne JB. Metode Fitokimia. Penuntun Cara Modern menganalisis Tumbuhan. Terbitan Kedua. Penerbit ITB Bandung; 1987.

10.Anatomic Pathology Laboratory. Modified Technique Histopathologic and cytology preparations Management in Anatomic Pathology Laboratory of the University of Padjadjaran. Hasan Sadikin Hospital. 2003;21-30.

11.Junqueira, L.C., Carneiro, J. 2005. Basic Histology Text \& Atlas. Eleventh edition. New York : McGraw-Hill.

12. Gartner LP, Hiatt JL. Color textbook of histology international edition. Third Edition. Saunders Elsevier. Philadelphia, PA 191032899. ISBN-13:978-1-4160- 2945-8. 2007;403-5

13.Hidayat, M., Prahastuti, S., Tiono, H., Dianawati, D.A., Marcella. Effect Of Calcium Against Weight Gain And Improved Histopathologic Fatty Liver On Male Wistar Rats That Fed High Fat Food. T3: O.011. $7^{\text {th }}$ Asia Oceania Conference Of Obesity. Obesity Research \& Clinical Practice. The Holistic Approach Of Obesity And Related Disease In The Asia-Oceania Perspective Insight On Local Resources For
Management Of Obesity And Related Diseases. October 2013. Bandung, Indonesia. 14.Bagchi D, Carryl OR, Tran MX, Khorn R.L, Bagchi DJ, Garg A, et al. Stress, diet and alcohol- nduced oxidative gastrointestinal mucosal injury in rats and protection by bismuth subsalicylate. J. Appl. Toxicol. 1998;18:3-13.

Available:http://www.ncbi.nlm.nih.gov/pub med/9526828Onlinelibrary.wiley.com/journ al/10.1002/(ISSN)1099-1263 Underwood. [Cited : Febuary $10^{\text {th }}, 2015$ ] Responses to Cellular Injury Chapter 4. 1999.

15.Hidayat, M., Kurnia, D., Sujatno, M., Sutadipura, N., Setiawan. 2010. Comparison Of Macronutrition And Isoflavone Content In Detam 1 And Wilis Seed, Tempeh, And Soybean Extracts And Its Potential In Decreasing Body Weight. Bionatura. 2010; (12) : 5-13.

16. Fonnesu, A., Severi, C. Oxidative Phosphorylation In Mitochondria from Livers Showing Cloudy Swelling. Institute of General Pathology, University of Milan, Milan, Italy. 1956.

17.Silitonga, Rhoito Frista. Daya Inhibisi Ekstrak Daun Jati Belanda dan Bangle Terhadap Aktivitas Lipase Pankreas Sebagai Antiobesitas. 2008.

18.Dowman, J.K., Tomlinson J.W., Newsome P.N. Pathogenesis Of Non-alcoholic Fatty Liver Disease. [Cited : January 15th, 2015] http://m.qjmed.oxfordjournals.org/content/1 03/2/71. 2010.

19.M. Yalniz, I. H. Bahcecioglu, N. Kuzu et al. Preventive Role Of Genistein In An Experimental Non-Alcoholic Steatohepatitis Model. [Cited : January 16th, 2015] http://onlinelibrary.wiley.com/enhanced/doi/ 10.1111/j.1440-1746.2006.04681.x. 2007.

20.Leng L, Jiang ZQ, Ji GY. Effects of soybean isoflavone on liver lipid metabolism in nonalcoholis fatty liver rats. Zhonghua $\mathrm{Yu}$ Fang Yi Xue Za Zhi. 2011; 45(4):335-9. PubMed 21624329.

21.Bayupurnama P. Hepatotoksisitas Imbas Obat. Buku Ajar Ilmu Penyakit Dalam Edisi ke-4. Jakarta : Pusat Penerbitan Departemen Ilmu Penyakit Dalam FKUI. 2006.

22.Causes of Plant Toxin-induced liver 
damage- Tannic acid. 2015. Right Diagnosis from Healthgrades. www. ightdiagnosis.com/p/plant_toxin_induced_li ver__damage_tannic_acid/causes.htm. https://tannic acid.wordpress.com/how-safeis-tannix-acid-disadvantages.

23.Lucke HH, Hodge KE, Patt NL. Fatal Liver
Damage after barium enemas containing Tannic Acid. Can Med Assoc J. 1963. 30;89:1111-4

24. WebMD.

www.webmed.com.ingredientmono-217tannic: Tannic acid: uses, side effects, interactions and warnings-WebMD 